\title{
Application of response surface methodology to the modeling of cellulase purification by solvent extraction
}

\author{
Jagdish Singh*, Anamika Sharma \\ Department of Biotechnology, Mata Gujri College, Fatehgarh Sahib, India \\ Email:*jagdish122@rediffmail.com
}

Received 12 May 2012; revised 27 June 2012; accepted 1 July 2012

\begin{abstract}
Central composite design (CCD) concerning the purification of cellulase from the Bacillus sp. JS14 in a solvent extraction was established with Response surface methodology (RSM). Solvent concentration, $\mathrm{pH}$, temperature and retention time were selected as process variables to evaluate the purification impact factor in solvent precipitation, including the purification fold and \% recovery. An experimental space with 13 purification fold and 23 recovery percentage recovery is achieved through the optimized condition based on the model. The molecular weight of the purified enzyme was estimated to be $32.5 \mathrm{KDa}$. Optimum activity of purified enzyme was at $\mathrm{pH}$ and temperature $6.5^{\circ} \mathrm{C}$ and $40^{\circ} \mathrm{C}$ respectively. Enzyme showed maximum activity with carboxymethyl cellulose as substrate with compare to rice husk, wheat straw and sucrose. The purified cellulase activity was inhibited by $\mathrm{Na}^{+}, \mathrm{Cl}^{-}, \mathrm{Mg}^{2+}$ Tween 80 and EDTA.
\end{abstract}

Keywords: Cellulase; Purification; Solvent Extraction; Response Surface Methodology

\section{INTRODUCTION}

Cellulosic material is the most abundant renewable carbon source in the world $[1,2]$. Cellulose is possible substitutes for diminishing fossil energy resources and becoming increasingly important. With the shortage of petroleum fuels and air pollution due to the incomplete combustion of fossil fuel, there has been increasing worldwide interest in the production of bioethanol from lignocellulosic biomass. To utilize these materials and to avoid waste pollution, one of the most important approaches is to find appropriate cellulase enzyme to hydrolyze the lignocellulosic biomass to produce glucose, which is used for the production of ethanol, organic acids etc. Cellulase (E.C 3.2.1.4) refers to a class of enzymes that catalyze the hydrolysis of $1,4 \beta$-D glycosidic linkages in cellulose are mainly produced by fungi, bacteria

"Corresponding author. and protozoans [3] and have broad range of applications especially in animal feed, textile, waste water treatment, brewing and wine-making [4-7]. An important obstruction in the exploitation of cellulase is expensive purification effecting the overall cost of hydrolysis [8-11].

The problems in the purification of enzyme are an impenetrability in the development of economically feasible bioprocess. Impact of combinatorial interactions of different parameters for the solvent extraction of desired compound is abundant. Response surface methodology (RSM), which is a collection of statistical techniques for designing experiments, building models, evaluating the effects of factors and searching for the optimum conditions, has successfully been used in the optimization of bioprocesses [12-14]. To illuminate the relationship among the recovery percentage and solvent concentration a statistical model is established by response surface methodology and validated with experimental data in this research paper. The present communication illustrate efficiency of statistical techniques for designing solvents extraction system for the purification of cellulase enzyme from the fermented broth with respect to the costly chromatography reliant purification matrixes. The results revealed the development of a practical criterion for solvent extraction of enzyme

\section{MATERIALS AND METHODS}

\subsection{Microorganism and Enzyme Production}

The Bacillus sp. JS14, isolated from soil in laboratory, was cultured in a medium containing $(\mathrm{g} / \mathrm{l}) \mathrm{KH}_{2} \mathrm{PO}_{4}, 0.1$; $\mathrm{MgSO}_{4} \cdot 7 \mathrm{H}_{2} \mathrm{O}, 0.2$; CMC, 10.0; Yeast extract, 1.0; Peptone, 1.0; $\mathrm{Na}_{2} \mathrm{HPO}_{4}, 2.5 ;\left(\mathrm{NH}_{4}\right)_{2} \mathrm{SO}_{4}, 1.0 ; \mathrm{pH}$ 7.0. The culture was kept at agitation speed of $150 \mathrm{rpm}$ and $37^{\circ} \mathrm{C}$. The supernatant was harvested after $36 \mathrm{~h}$ cultivation by centrifugation at $10000 \mathrm{~g}$ for $20 \mathrm{~min}$ and stored at $4^{\circ} \mathrm{C}$ for further use.

\subsection{Experimental Design and Statistical Analysis for Solvent Extraction of Cellulase Enzyme}

Response surface methodology (RSM) involving a cen- 
tral composite design (CCD) and a second-order polynomial equation was employed to identify the relationship between four significant variables that influence cellulase extraction significantly. The central values (zero level) chosen for experimental design were; acetone $\left(\mathrm{X}_{1}\right)$, $50 \% ; \mathrm{pH}\left(\mathrm{X}_{2}\right), 5.5$; Temperatures, $\left(\mathrm{X}_{3}\right) 17^{\circ} \mathrm{C}$ and incubation Time $\left(\mathrm{X}_{4}\right) 6.5 \mathrm{~h}$ in CCD I (Table 1). Different combination of variables was used according to the CCD design I (Table 2) for the determination of purification fold and $\%$ recovery.

Enzyme purification achieved by acetone was further extracted with ethanol solvent according to the CCD design II (Tables 1 and 2) .The Design expert 8.0.1 software, was used for regression and graphical analyses. The optimal concentrations of critical solvents were obtained by ridge analysis and contour plots. The statistical analysis of the model was performed in the form of analysis of variance (ANOVA) for the determination of significant variables.

\subsection{Validation of Model}

The optimized conditions generated during response surface methodology implementation were validated by conducting extraction experiment on given optimal setting conditions. Study was carried out in triplicate to confirm the results.

\subsection{Cellulase Assay and Protein Determination}

The cellulase (CMCase) activity was assayed according to Stewart and Leatherwood (1976). Appropriately enzyme solution $(0.5 \mathrm{ml})$ was added to $0.5 \mathrm{ml} \mathrm{CMC}(0.5 \%$ CMC dissolved in sodium acetate buffer $0.2 \mathrm{M}, \mathrm{pH} 5.0$ ) and incubated at $60^{\circ} \mathrm{C}$ for 30 minutes. The reaction was stopped by the addition of $3.0 \mathrm{ml}$ of 3,5-dinitrosalicylic acid reagent [15] and $A_{540}$ was measured in a Shimadzu
UV-160A spectrophotometer. One international unit (IU) of enzyme activity was defined as the amount of enzyme that catalyzed the liberation of reducing sugar equivalent to $1.0 \mu \mathrm{M}$ glucose $\mathrm{min}^{-1}$ under assay conditions. The protein concentration of the crude and purified enzyme fractions was determined by the method of Lowry et al., [16] using bovine serum albumin (BSA) as standard.

\subsection{SDS-PAGE}

SDS-polyacrylamide gel electrophoresis (SDS-PAGE) was performed on $12.5 \%(\mathrm{w} / \mathrm{v})$ acrylamide slab gel with $25 \mathrm{mM}$ Tris for the determination of molecular weight, as described by Laemmli [17].

\subsection{Optimum Temperature, $\mathrm{pH}$ and Thermal Stability of Purified Cellulase}

Optimum temperature for activity enzyme was determined by carrying out cellulose hydrolysis at various temperatures i.e. $20^{\circ} \mathrm{C}, 30^{\circ} \mathrm{C}, 40^{\circ} \mathrm{C}, 50^{\circ} \mathrm{C}$ and $60^{\circ} \mathrm{C}$. In each case, the substrate was preincubated at the required temperature before the addition of enzyme. The optimum $\mathrm{pH}$ was determined by monitoring cellulase activity at $\mathrm{pH}$ values 4.0, 5.0, 6.0, 6.5, 7.0 and 8.0 using different buffers.

\subsection{Determination of Kinetic Parameters}

Enzyme was incubated with various concentrations of carboxy methyl cellulose $(0.05 \%, 0.1 \%, 0.2 \%, 0.5 \%$ and $1.0 \%$ ) at $\mathrm{pH} 6.5$ and temperature $40^{\circ} \mathrm{C}$. Kinetic parameters $\mathrm{K}_{\mathrm{m}}$ and $\mathrm{V}_{\max }$ were calculated by linear regression from Line weaver Burk plot [18]. The substrate specificity of enzyme was tested for $\mathrm{CMC}$, rice husk, wheat straw and sucrose. Chemical factors $\mathrm{NaCl}, \mathrm{MgSO}_{4}$, Tween 20 and EDTA at $5 \mathrm{mM}$ final concentration was used to

Table 1. Different parameters for purification using Response Surface Methodology.

\begin{tabular}{|c|c|c|c|c|c|}
\hline \multirow{2}{*}{ Factor } & \multicolumn{5}{|c|}{ CCD Design (I) for Acetone Extraction } \\
\hline & Name & Units & Low Actual (-1) & Value (0) & High Actual (+1) \\
\hline $\mathrm{X}_{2}$ & $\mathrm{pH}$ & & 4.00 & 5.5 & 7.00 \\
\hline $\mathrm{X}_{3}$ & Temp. & ${ }^{\circ} \mathrm{C}$ & 4.00 & 17 & 30.00 \\
\hline \multirow[t]{2}{*}{$\mathrm{X}_{4}$} & Time & Hrs & 1.00 & 6.5 & 12.00 \\
\hline & \multicolumn{5}{|c|}{ CCD Design (II) for Ethanol Extraction } \\
\hline $\mathrm{X}_{1}$ & Ethanol & $\%$ & 10.00 & 50 & 90.00 \\
\hline $\mathrm{X}_{2}$ & $\mathrm{pH}$ & & 4.00 & 5.5 & 7.00 \\
\hline$X_{4}$ & Time & Hrs & 1.00 & 6.5 & 12.00 \\
\hline
\end{tabular}


Table 2. A central composite design (CCD) for extraction of cellulase using Response surface methodology by acetone and ethanol solvents.

\begin{tabular}{|c|c|c|c|c|c|c|c|c|c|c|c|}
\hline \multicolumn{6}{|c|}{ CCD I for Acetone Extraction } & \multicolumn{6}{|c|}{ CCD II for Ethanol Extraction } \\
\hline \multicolumn{4}{|c|}{ Values of Factors ${ }^{*}$} & \multirow{2}{*}{$\begin{array}{c}\text { Response I } \\
\text { Purification Fold }\end{array}$} & \multirow{2}{*}{$\begin{array}{l}\text { Response II } \\
\text { \% Recovery }\end{array}$} & \multicolumn{4}{|c|}{ Values of Factors** } & \multirow{2}{*}{$\begin{array}{c}\text { Response I } \\
\text { Purification Fold }\end{array}$} & \multirow{2}{*}{$\begin{array}{l}\text { Response II } \\
\text { \% Recovery }\end{array}$} \\
\hline $\mathbf{X}_{1}$ & $\mathbf{X}_{2}$ & $\mathbf{X}_{3}$ & $\mathbf{X}_{4}$ & & & $\mathbf{X}_{1}$ & $\mathbf{X}_{2}$ & $\mathbf{X}_{3}$ & $\mathbf{X}_{4}$ & & \\
\hline 10 & 7 & 4 & 1 & 0.04 & 7.9 & 130 & 5.50 & 17 & 6.50 & 0 & 0 \\
\hline 10 & 7 & 4 & 12 & 0.03 & 5.34 & 50 & 5.50 & 17 & 6.50 & 0.93 & 13.4 \\
\hline 50 & 5.50 & 17 & 6.50 & 2 & 29.36 & 10 & 7 & 30 & 12 & 1.68 & 16.66 \\
\hline 10 & 7 & 30 & 1 & 0.05 & 7.93 & 30 & 5.50 & 17 & 6.50 & 1.45 & 14.2 \\
\hline 10 & 4 & 4 & 1 & 1.01 & 7.94 & 50 & 2.50 & 17 & 6.50 & 1.77 & 13.4 \\
\hline 10 & 7 & 30 & 12 & 0.03 & 48 & 50 & 5.50 & 17 & 4.50 & 1.24 & 13.4 \\
\hline 50 & 5.50 & 17 & 17.50 & 0.47 & 14.2 & 10 & 4 & 4 & 1 & 6 & 15 \\
\hline 90 & 4 & 30 & 12 & 1.31 & 18.6 & 10 & 4 & 4 & 12 & 13 & 23 \\
\hline 10 & 4 & 4 & 12 & 0.61 & 2.07 & 50 & 5.50 & 17 & 17.50 & 2.1 & 4.8 \\
\hline 90 & 7 & 30 & 1 & 0.128 & 48 & 90 & 4 & 30 & 12 & 3.85 & 1.4 \\
\hline 30 & 5.50 & 17 & 6.50 & 0.81 & 10.23 & 10 & 7 & 4 & 1 & 1.58 & 9.7 \\
\hline 50 & 8.50 & 17 & 6.50 & 0.42 & 14.2 & 10 & 7 & 4 & 12 & 2.57 & 8.57 \\
\hline 50 & 2.50 & 17 & 6.50 & 0.85 & 14.2 & 90 & 7 & 4 & 12 & 4.435 & 1.4 \\
\hline 50 & 5.50 & 43 & 6.50 & 0.85 & 14.2 & 90 & 7 & 30 & 1 & 0.88 & 0.89 \\
\hline 90 & 7 & 30 & 12 & 0.056 & 23.3 & 50 & 8.50 & 17 & 6.50 & 1.18 & 4.8 \\
\hline 90 & 4 & 4 & 12 & 1.21 & 18.6 & 10 & 4 & 30 & 1 & 1.42 & 6.9 \\
\hline 90 & 4 & 4 & 1 & 1.6 & 77 & 90 & 7 & 30 & 12 & 4.26 & 0.96 \\
\hline 130 & 5.50 & 17 & 6.50 & 0 & 0 & 50 & 5.50 & 43 & 6.50 & 1.027 & 4.8 \\
\hline 50 & 5.50 & 9 & 6.50 & 1.07 & 14.2 & 10 & 7 & 30 & 1 & 3.8 & 6.9 \\
\hline 10 & 4 & 30 & 1 & 0.37 & 2.07 & 90 & 4 & 4 & 1 & 2.7 & 0.84 \\
\hline 10 & 4 & 30 & 12 & 0.426 & 2.07 & 90 & 4 & 30 & 1 & 3.8 & 0.84 \\
\hline 50 & 5.50 & 17 & 4.50 & 0.65 & 14.2 & 10 & 4 & 30 & 12 & 3.38 & 17 \\
\hline 90 & 7 & 4 & 12 & 0.069 & 23.3 & 90 & 4 & 4 & 12 & 2.6 & 0.96 \\
\hline 90 & 4 & 30 & 1 & 1.37 & 71.4 & 90 & 7 & 4 & 1 & 2.7 & 0.84 \\
\hline 90 & 7 & 4 & 1 & 0.67 & 48 & 50 & 5.50 & 9 & 6.50 & 1.1 & 4.8 \\
\hline
\end{tabular}

${ }^{*} \mathrm{X}_{1}$ (Acetone), $\mathrm{X}_{2}(\mathrm{pH}), \mathrm{X}_{3}$ (temperature), $\mathrm{X}_{4}$ (retention time); ${ }^{* *} \mathrm{X}_{1}\left(\right.$ Ethanol), $\mathrm{X}_{2}(\mathrm{pH}), \mathrm{X}_{3}$ (temperature), $\mathrm{X}_{4}$ (retention time).

verify the rate of enzyme activation and inhibition.

\section{RESULTS AND DISCUSSION}

\subsection{Response Surface Experimental Design}

Optimum levels of the key factors and their effect of interactions were determined by central composite design of RSM. Purification fold and \% recovery of 1.7 and 77 respectively was achieved with optimum parameters i.e.; acetone $\left(\mathrm{X}_{1}\right) 90 \%, \mathrm{pH}\left(\mathrm{X}_{2}\right) 4$, temperature $\left(\mathrm{X}_{3}\right) 4^{\circ} \mathrm{C}$ and incubation period $\left(\mathrm{X}_{4}\right) 1 \mathrm{~h}$. (Table 2). Regression equation obtained after the analysis of variance gave the 
level of response as a function of three independent variables. A quardratic model was attempted to fit the data by least squares and all terms regard less of their significance were included in the following equation:

$$
\begin{aligned}
\mathrm{y}= & 284.09494+37.31286 \mathrm{X}_{1}+225.23766 \mathrm{X}_{2} 43.47243 \mathrm{X}_{3} \\
& +790.58161 \mathrm{X}_{4}+28.95995 \mathrm{X}_{1} \mathrm{X}_{2}+0.043204 \mathrm{X}_{1} \mathrm{X}_{3} \\
& +0.28792 \mathrm{X}_{1} \mathrm{X}_{4}+64.21602 \mathrm{X}_{2} \mathrm{X}_{3}+0.011021 \mathrm{X}_{2} \mathrm{X}_{4} \\
& +1.14198 \mathrm{X}_{3} \mathrm{X}_{4}-2.47136 \mathrm{X}_{1}^{2}-261.78389 \mathrm{X}_{2}^{2}
\end{aligned}
$$

where $\mathrm{y}$ is the measured response, and $\mathrm{X}_{1}, \mathrm{X}_{2}, \mathrm{X}_{3}$ and $\mathrm{X}_{4}$ are coded independent variables.

After the purification with the acetone another solvent ethanol was used for the extraction of cellulase by central composite design with Quadratic Design to determine the optimum levels of variables. Purification fold and \% recovery of 13 and 23 respectively was achieved with the conditions having ethanol $\left(\mathrm{X}_{1}\right) 10 \%, \mathrm{pH}\left(\mathrm{X}_{2}\right) 4$, temperature $\left(\mathrm{X}_{3}\right) 4^{\circ} \mathrm{C}$ and retention time $\left(\mathrm{X}_{4},\right) 12 \mathrm{~h}$. Regression analysis was performed to fit the response function with the experimental data. The statistical significance of the second order model equation was checked by an F-test (ANOVA) and the data are shown in Table 3. The regression model for cellulase production was highly significant with a satisfactory value of determination. The Model F-value implied the model is significant.
There is only a $0.01 \%$ chance that a "Model F-Value" this large could occur due to noise. Values of "Prob $>$ F" less than 0.0500 indicated that the model terms were significant. The "Pred R-Squared" was as close to the "Adj R-Squared" as one might normally expect. "Adeq Precision" value measures the signal to noise ratio and greater than 4 is desirable as an adequate signal. These facts indicated that the model equation as expressed in Eq.1 provided a suitable model to describe the response of the experiment pertaining to percentage recovery. It can be noticed from the degree of significance (Table 4) that the regression coefficients of linear and quadratic coefficients of $X_{1}, X_{2}$ and $X_{3}$ were significant at $1 \%$ level This model can be used to navigate the design space. The 3D contours response surface graph based on dependent variables are shown in Figures 1-4. The canonical analysis revealed a effects of variables for maximum purification fold and percentage recovery.

\subsection{Model Application}

The purification fold and percentage recovery of 13 and 23 respectively (16.7 IU $\cdot \mathrm{mg}^{-1}$ protein) (Table 5) was achieved with the conditions having ethanol $\left(\mathrm{X}_{1}\right) 10 \%$, $\mathrm{pH}\left(\mathrm{X}_{2}\right) 4$, temperature $\left(\mathrm{X}_{3}\right) 4^{\circ} \mathrm{C}$ and retention time $\left(\mathrm{X}_{4}\right)$,

\begin{tabular}{|c|c|c|c|c|c|c|c|c|c|c|c|}
\hline \multicolumn{6}{|c|}{ CCD I1 Response I (Purification Fold) } & \multicolumn{6}{|c|}{ CCD I1 Response II (\% Recovery) } \\
\hline Source & $\begin{array}{l}\text { Sum of } \\
\text { Squares }\end{array}$ & df & $\begin{array}{c}\text { Mean } \\
\text { Square }\end{array}$ & F Value & $\begin{array}{l}\text { p-Value } \\
\text { Prob }>\text { F }\end{array}$ & Source & $\begin{array}{c}\text { Sum of } \\
\text { Squares }\end{array}$ & df & $\begin{array}{c}\text { Mean } \\
\text { Square }\end{array}$ & F Value & $\begin{array}{c}\text { p-Value } \\
\text { Prob }>\text { F }\end{array}$ \\
\hline Model & 7.07 & 14 & 0.51 & 4.12 & $\begin{array}{c}0.0050 \\
\text { Significant }\end{array}$ & Model & 9762.48 & 14 & 697.32 & 4.64 & 0.0027 \\
\hline $\mathrm{X}$-Ethano & 0.96 & 1 & 0.96 & 7.85 & 0.0134 & X-Ethano & 3256.97 & 1 & 3256.97 & 21.69 & 0.0003 \\
\hline $\mathrm{X}_{2}-\mathrm{pH}$ & 2.85 & 1 & 2.85 & 23.24 & 0.0002 & $\mathrm{X}_{2}-\mathrm{pH}$ & 46.00 & 1 & 46.00 & 0.31 & 0.5881 \\
\hline $\mathrm{X}_{3}$-Temp. & 0.21 & 1 & 0.21 & 1.68 & 0.2151 & $\mathrm{X}_{3}$-Temp & 0.33 & 1 & 0.33 & $2.218 \mathrm{E}-003$ & 0.9631 \\
\hline $\mathrm{X}_{4}$-Time & 0.22 & 1 & 0.22 & 1.76 & 0.2046 & $\mathrm{X}_{4}$-Time & 1505.66 & 1 & 1505.66 & 10.03 & 0.0064 \\
\hline $\mathrm{X}_{1} \mathrm{X}_{2}$ & 0.32 & 1 & 0.32 & 2.65 & 0.1244 & $\mathrm{X}_{1} \mathrm{X}_{2}$ & 693.00 & 1 & 693.00 & 4.61 & 0.0484 \\
\hline $\mathrm{X}_{1} \mathrm{X}_{3}$ & $9.882 \mathrm{E}-003$ & 1 & $9.882 \mathrm{E}-003$ & 0.081 & 0.7802 & $\mathrm{X}_{1} \mathrm{X}_{3}$ & 274.68 & 1 & 274.68 & 1.83 & 0.1963 \\
\hline $\mathrm{X}_{1} \mathrm{X}_{3}$ & 0.025 & 1 & 0.025 & 0.20 & 0.6573 & $\mathrm{X}_{1} \mathrm{X}_{3}$ & 2630.48 & 1 & 2630.48 & 17.52 & 0.0008 \\
\hline $\mathrm{X}_{2} \mathrm{X}_{3}$ & 0.024 & 1 & 0.024 & 0.19 & 0.6673 & $\mathrm{X}_{2} \mathrm{X}_{3}$ & 201.19 & 1 & 201.19 & 1.34 & 0.2652 \\
\hline $\mathrm{X}_{2} \mathrm{X}_{4}$ & $2.004 \mathrm{E}-003$ & 1 & $2.004 \mathrm{E}-003$ & 0.016 & 0.8999 & $\mathrm{X}_{2} \mathrm{X}_{4}$ & 1080.18 & 1 & 1080.18 & 7.19 & 0.0171 \\
\hline $\mathrm{X}_{3} \mathrm{X}_{4}$ & 0.15 & 1 & 0.15 & 1.25 & 0.2817 & $\mathrm{X}_{3} \mathrm{X}_{4}$ & 200.74 & 1 & 200.74 & 1.34 & 0.2657 \\
\hline Residual & 1.84 & 15 & 0.12 & & & Residual & 2252.47 & 15 & 150.16 & & \\
\hline Lack of Fit & 1.84 & 10 & 0.18 & & & Lack of Fit & 2252.47 & 10 & 225.25 & & \\
\hline Pure Error & 0.000 & 5 & 0.000 & & & Pure Error & 0.000 & 5 & 0.000 & & \\
\hline Cor Total & 8.91 & 29 & & & & Cor Total & 12014.94 & 29 & & & \\
\hline
\end{tabular}
$12 \mathrm{~h}$ with the CCD experimental results of cellulase purification. Established model is satisfactory and confirms

Table 3. ANOVA results for cellulase purification obtained from ethanol extraction. 
Table 4. ANOVA results for cellulase purification obtained from acetone extraction.

\begin{tabular}{|c|c|c|c|c|c|c|c|c|c|c|c|}
\hline \multicolumn{6}{|c|}{ CCD 1 Response I (Purification Fold) } & \multicolumn{6}{|c|}{ CCD 1 Response II ( \% Recovery) } \\
\hline Source & $\begin{array}{l}\text { Sum of } \\
\text { Squares }\end{array}$ & df & $\begin{array}{l}\text { Mean } \\
\text { Square }\end{array}$ & F Value & $\begin{array}{l}\text { p-Value } \\
\text { Prob > F }\end{array}$ & Source & $\begin{array}{c}\text { Sum of } \\
\text { Squares }\end{array}$ & Df & $\begin{array}{c}\text { Mean } \\
\text { Squares }\end{array}$ & F Value & $\begin{array}{l}\text { p-Value } \\
\text { Prob }>\text { F }\end{array}$ \\
\hline Model & 7.51 & 14 & 0.54 & 4.47 & $\begin{array}{c}0.0034 \\
\text { significant }\end{array}$ & Model & 9168.98 & 10 & 916.90 & 3.06 & $\begin{array}{c}0.0172 \\
\text { Significant }\end{array}$ \\
\hline $\mathrm{X}_{1}$ & 0.10 & 1 & 0.10 & 0.84 & 0.3750 & $X_{1}$ & 2678.04 & 1 & 2678.04 & 8.95 & 0.0075 \\
\hline $\mathrm{X}_{2}$ & 2.05 & 1 & 2.05 & 4.47 & 0.0009 & $\mathrm{X}_{2}$ & 12.15 & 1 & 12.15 & 0.041 & 0.8425 \\
\hline $\mathrm{X}_{3}$ & 0.066 & 1 & 0.066 & 0.55 & 0.4699 & $\mathrm{X}_{3}$ & 213.14 & 1 & 213.14 & 0.71 & 0.4093 \\
\hline $\mathrm{X}_{4}$ & 0.059 & 1 & 0.059 & 0.49 & 0.4960 & $\mathrm{X}_{4}$ & 1041.73 & 1 & 1041.73 & 3.48 & 0.0776 \\
\hline $\mathrm{X}_{1} \mathrm{X}_{2}$ & 0.16 & 1 & 0.16 & 1.35 & 0.2629 & $\mathrm{X}_{1} \mathrm{X}_{2}$ & 1010.94 & 1 & 1010.94 & 3.38 & 0.0818 \\
\hline $\mathrm{X}_{1} \mathrm{X}_{3}$ & 0.041 & 1 & 0.041 & 0.34 & 0.5683 & $\mathrm{X}_{1} \mathrm{X}_{3}$ & 0.27 & 1 & 0.27 & $8.868 \mathrm{E}-004$ & 0.9766 \\
\hline $\mathrm{X}_{1} \mathrm{X}_{3}$ & $2.326 \mathrm{E}-004$ & 1 & $2.326 \mathrm{E}-004$ & $1.935 \mathrm{E}-003$ & 0.9655 & $\mathrm{X}_{1} \mathrm{X}_{3}$ & 3061.99 & 1 & 3061.99 & 10.23 & 0.0047 \\
\hline $\mathrm{X}_{2} \mathrm{X}_{3}$ & $4.523 \mathrm{E}-003$ & 1 & $4.523 \mathrm{E}-003$ & 0.038 & 0.8488 & $\mathrm{X}_{2} \mathrm{X}_{3}$ & 11.90 & 1 & 11.90 & 0.040 & 0.8441 \\
\hline $\mathrm{X}_{2} \mathrm{X}_{4}$ & 0.002 & 1 & 0.022 & 0.18 & 0.6740 & $\mathrm{X}_{2} \mathrm{X}_{4}$ & 1126.93 & 1 & 1126.93 & 3.76 & 0.0673 \\
\hline $\mathrm{X}_{3} \mathrm{X}_{4}$ & 0.025 & 1 & 0.025 & 0.20 & 0.6576 & $\mathrm{X}_{3} \mathrm{X}_{4}$ & 11.90 & 1 & 11.90 & 0.040 & 0.8441 \\
\hline Residual & 1.80 & 15 & 0.12 & & & Residual & 5688.07 & 19 & 299.37 & & \\
\hline Lack of Fit & 1.80 & 10 & 0.18 & 2703.51 & $\begin{array}{c}0.0001 \\
\text { Significant }\end{array}$ & Lack of Fit & 5688.07 & 14 & 406.29 & & \\
\hline Pure Error & $3.333 \mathrm{E}-004$ & 5 & $6.667 \mathrm{E}-005$ & & & Pure Error & 0.000 & 5 & 0.000 & & \\
\hline Cor Total & 9.32 & 9 & & & & Cor Total & 14857.05 & 29 & & & \\
\hline
\end{tabular}

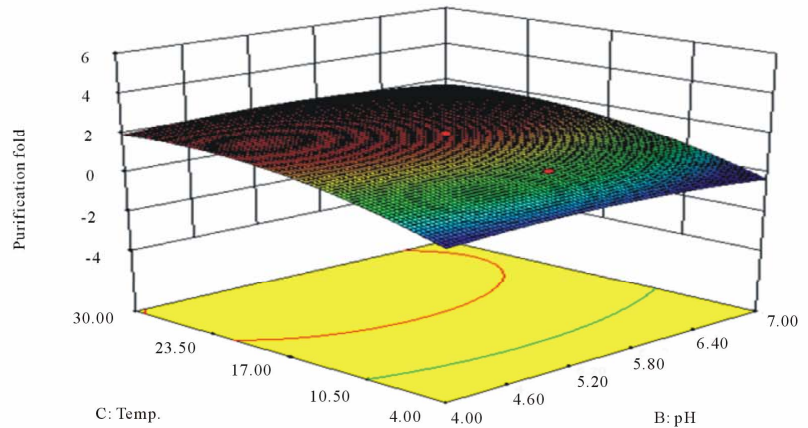

(a)

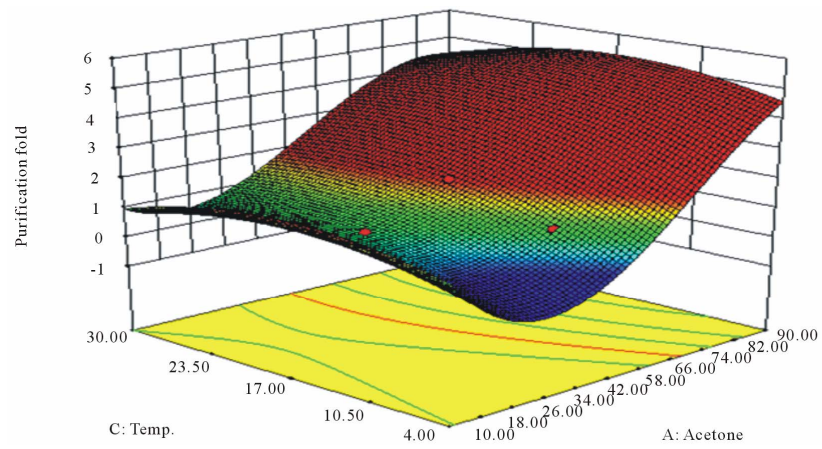

(c)

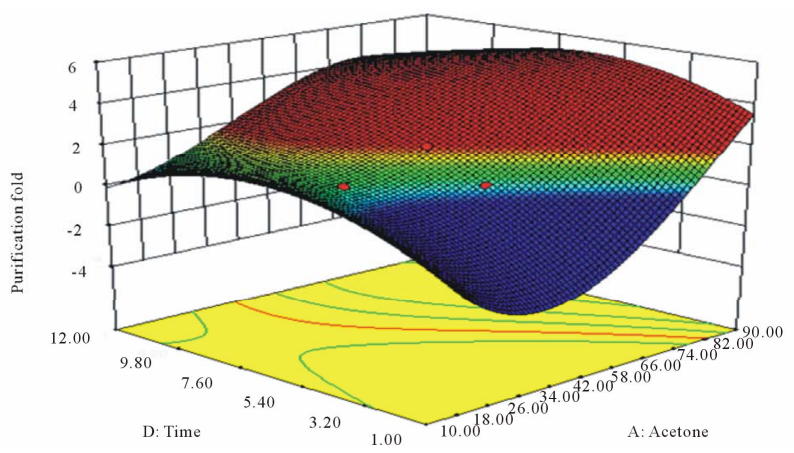

(b)

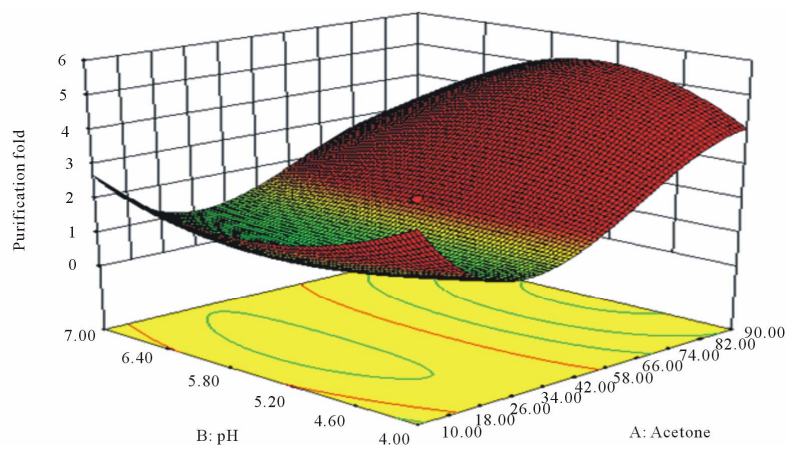

(d)

Figure 1. Surface plot for the effect of: (a) Temp and pH; (b) Time and acetone; (c) Temp and acetone; (d) pH and acetone conc. on purification fold by acetone extraction. 


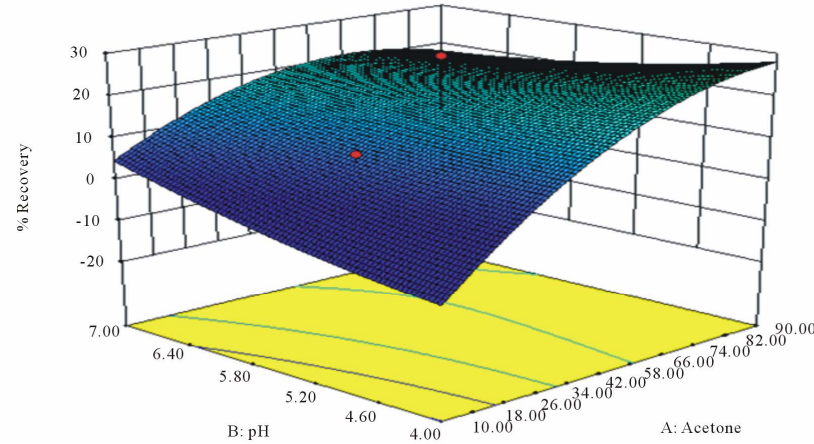

(a)

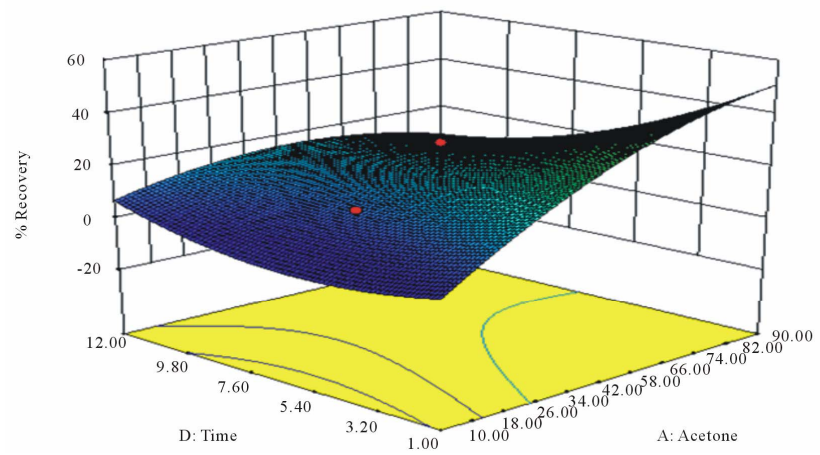

(c)

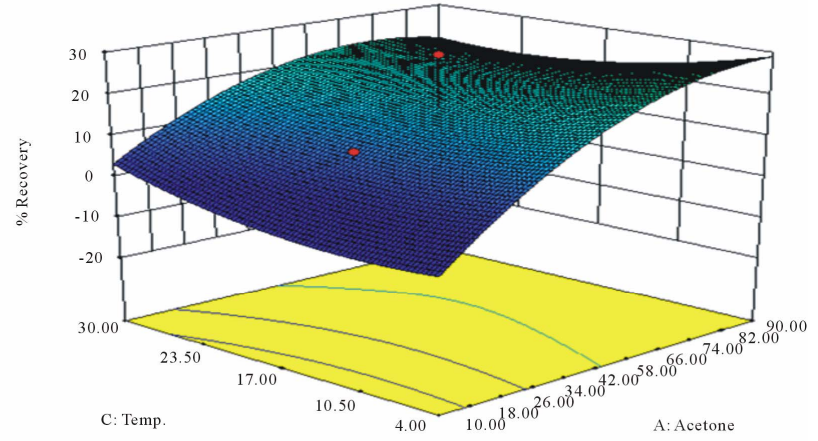

(b)

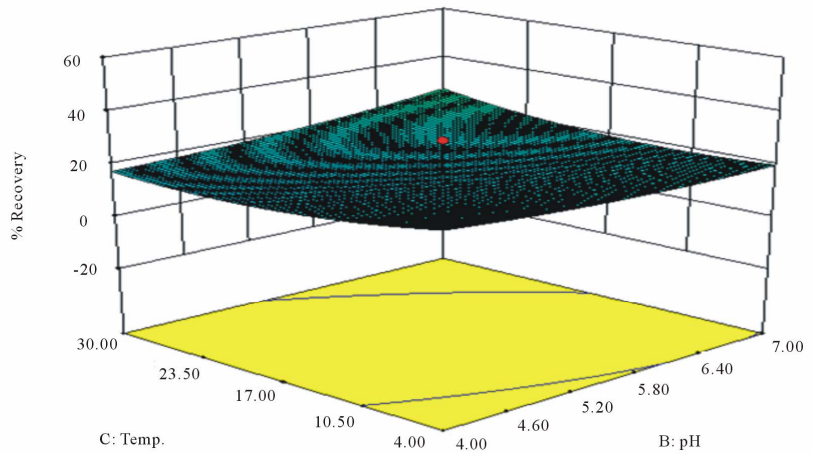

(d)

Figure 2. Surface plot for the effect of: (a) pH and acetone; (b) Temp and acetone; (c) Time and acetone; and (d) Temp and pH on \% recovery by acetone extraction.

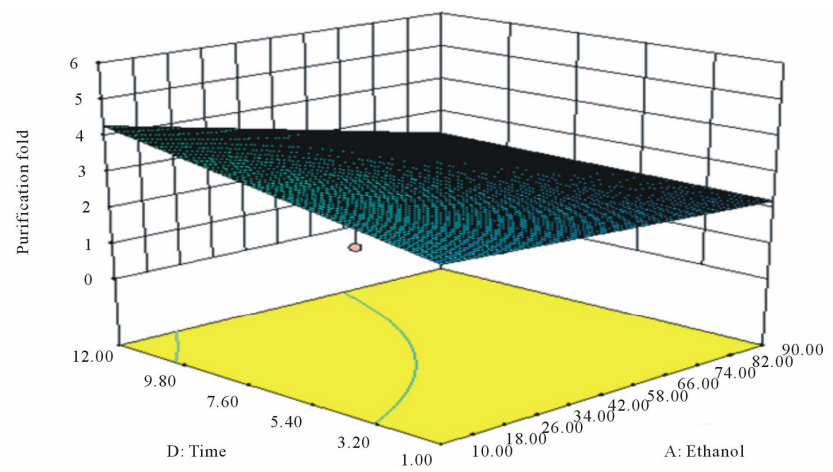

(a)

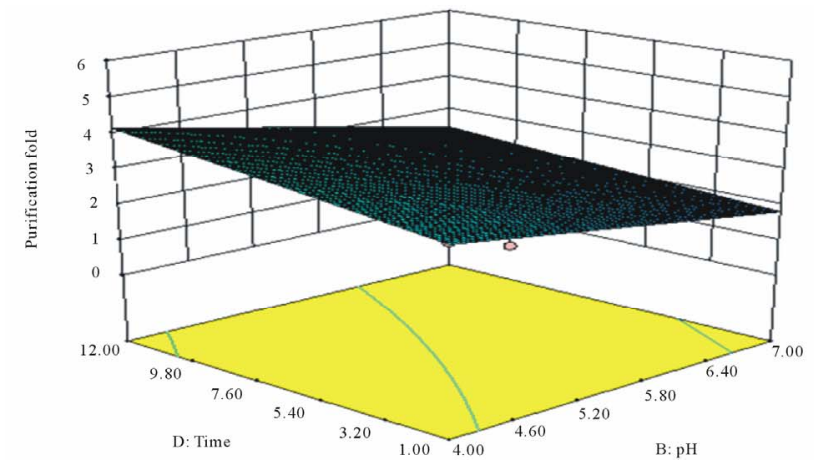

(c)

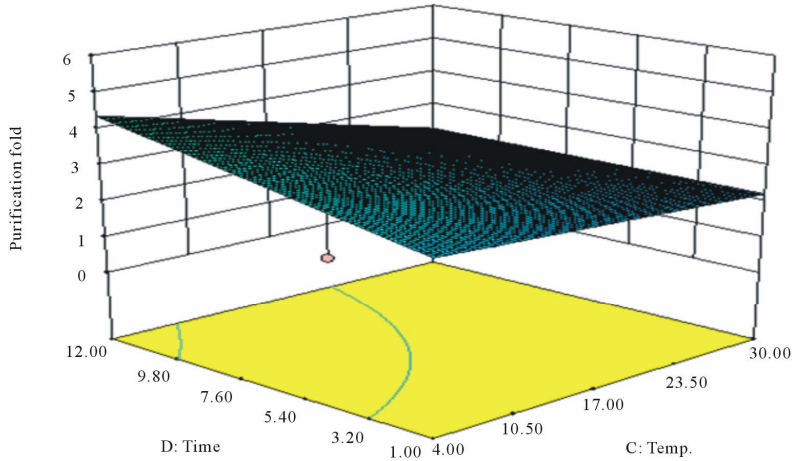

(b)

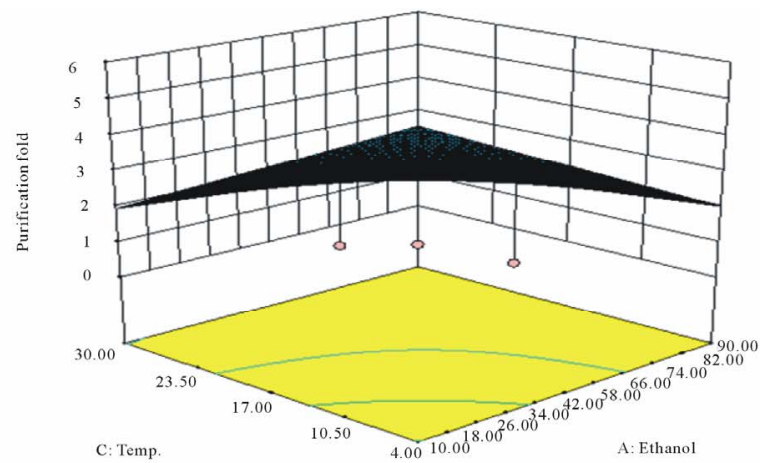

(d)

Figure 3. Surface plot for the effect of: (a) Time and ethanol con.; (b) Time and temp; (c) Time and pH; (d) Temp and ethanol conc. on purification fold by ethanol extraction. 


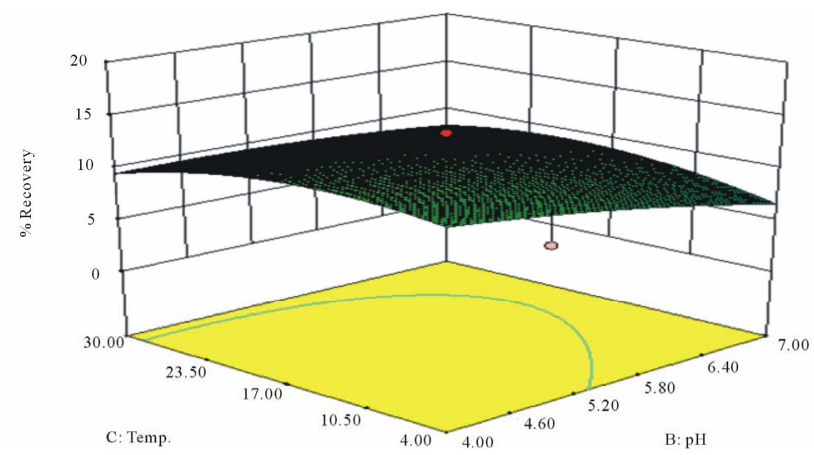

(a)

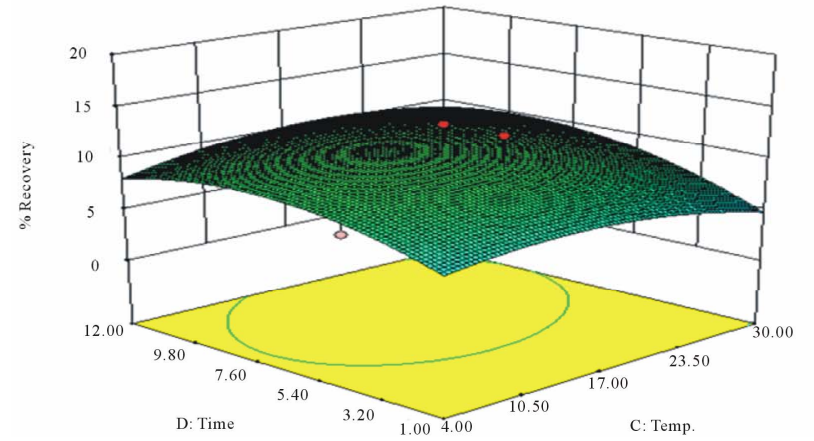

(c)

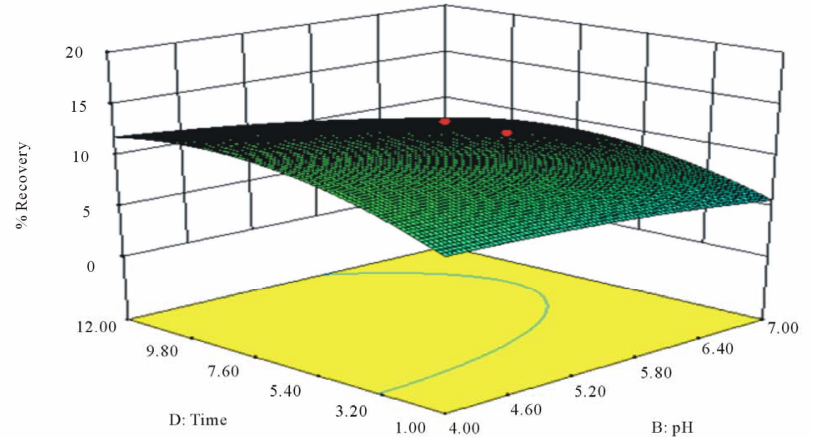

(b)

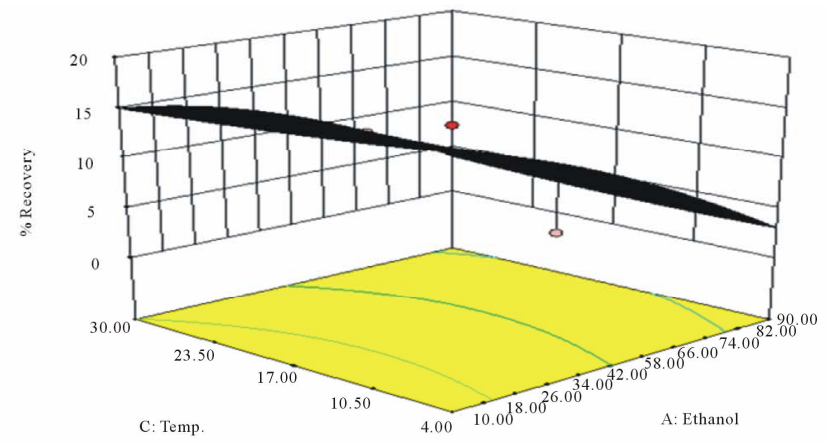

(d)

Figure 4. Surface plot for the effect of: (a) Temp and pH; (b) Time and pH; (c) Time and temp; (d) Temp and ethanol conc. on \% recovery by ethanol extraction.

Table 5. Over all purification of cellulase from Bacillus sp. JS14.

\begin{tabular}{cccccc}
\hline Methods & Enzyme Activity (IU) & Protein (mg) & Specific Activity (IU/mg of protein) & Purification-Ion Fold & Recovery (\%) \\
\hline Culture Filtrate & 1700 & 2200.0 & 0.77 & -- & 100 \\
Acetone Precipitation & 1300 & 1040 & 1.25 & 1.7 & 77 \\
Ethanol Precipitation & 299.9 & 18.40 & 16.25 & 13 & 23 \\
\hline
\end{tabular}

response surface methodology a promising tool in a design of complex process of purification in the selection of operating variables.

\subsection{Cellulase Characterization after Purification}

Results of Electrophoresis of the enzyme on SDS-PAGE showed that enzyme consist single polypeptide with a molecular weight of $32.5 \mathrm{KDa}$ (Figure 5) smaller than cellulase from $C$. thermophilum $(41 \mathrm{KDa}), C$. thermophilum $(36 \mathrm{KDa}), M$. thermophila $(100 \mathrm{KDa})$ and $H$. grisea $(63 \mathrm{kDa})$ [19-23]. The optimum $\mathrm{pH}$ and temperature for activity of the purified enzyme from Bacillus sp. $\mathrm{J} 14$ for standard assay conditions were $6.5^{\circ} \mathrm{C}$ and $40^{\circ} \mathrm{C}$ respectively (Figures 6(a) and (b)). This $\mathrm{pH}$ value is comparable to the optimum $\mathrm{pH}$ value of 7.0 for purified enzyme from Sinorhizobium fredii [14] and higher with respect to the optimum value of 5 for cellulase from Trichoderma viride [24]. At $40^{\circ} \mathrm{C}$ the cellulase was $98 \%$

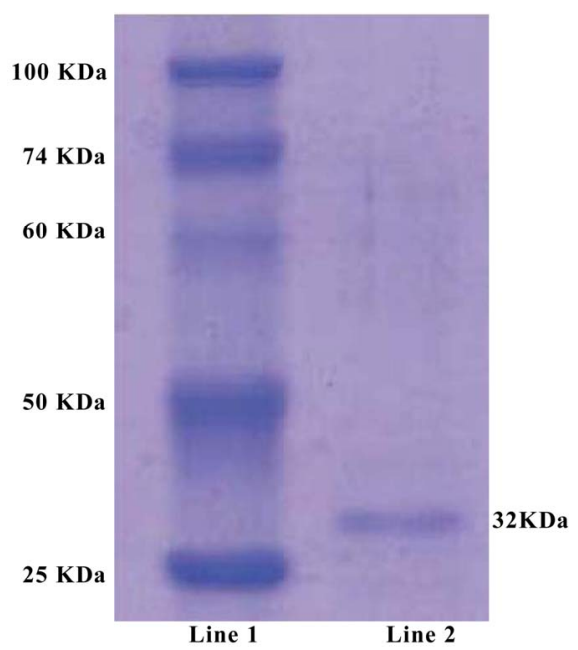

Figure 5. SDS-PAGE of purified cellulase from Bacillus JS14: Line 1 protein markers; Line 2: purified cellulase. 


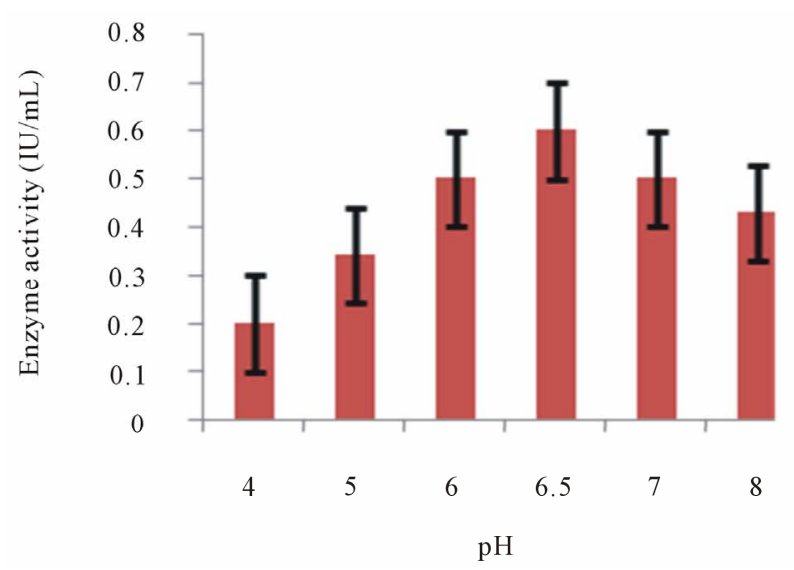

(a)

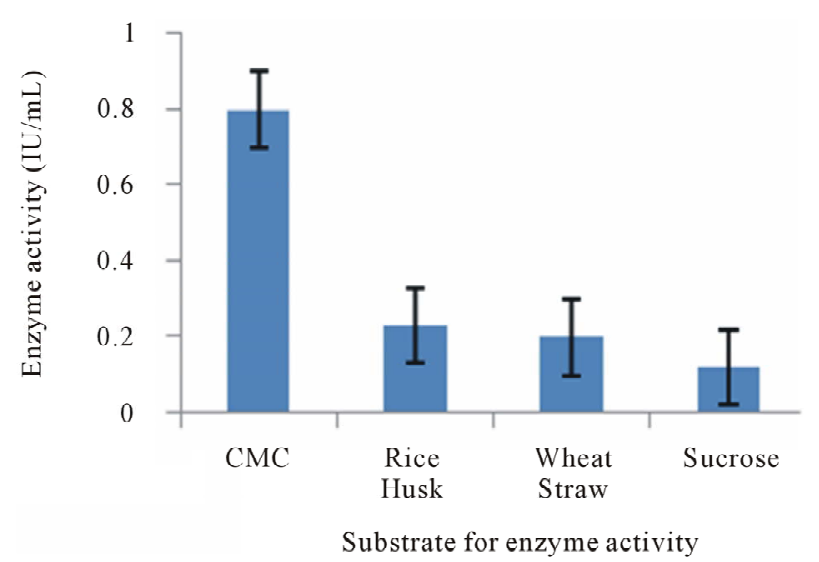

(c)

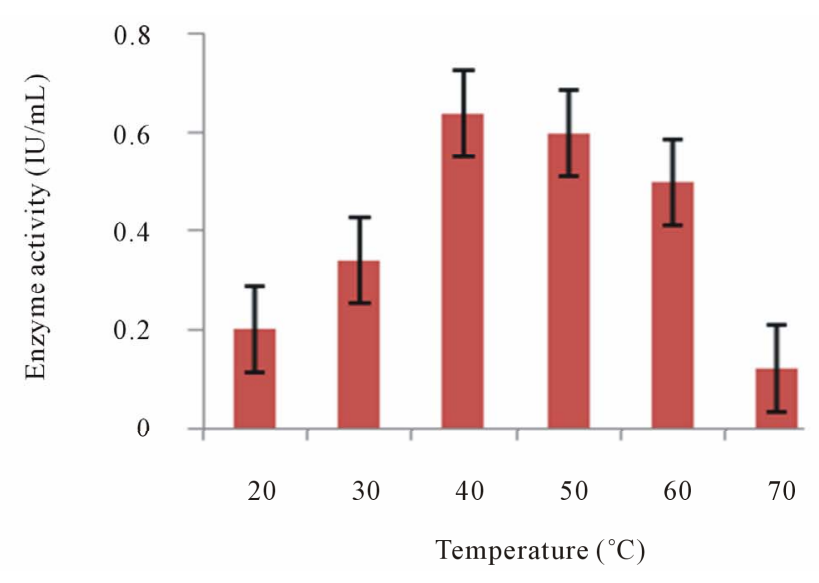

(b)

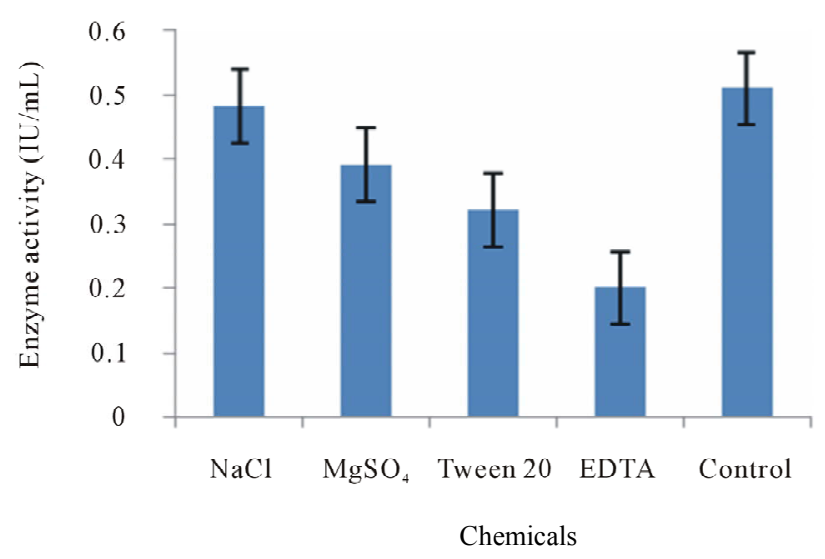

(d)

Figure 6. Effect of: (a) pH; (b) Temperature; (c) Substrates; and (d) Chemicals factors on the activity of purified enzyme.

stable and sharp decrease in activity was observed above $40^{\circ} \mathrm{C}$. Kinetic studies of the purified cellulase illustrated that $\mathrm{V}_{\max }$ and $\mathrm{K}_{\mathrm{m}}$ for purified enzyme was $66 \mathrm{IU} / \mathrm{mg}$ and $2.5 \mathrm{mg} \cdot \mathrm{mL}^{-1}$ respectively. Whereas $\mathrm{V}_{\max }$ and $\mathrm{K}_{\mathrm{m}}$ for cellulase was found to be $84 \mathrm{U} / \mathrm{mg}$ and $3.6 \mathrm{mg} \cdot \mathrm{mL}^{-1}$ respectively isolated from Bacteroides succinogene [25]. The $\mathrm{K}_{\mathrm{m}}$ is lower than the enzyme from the fungus $M$. thermophila $\left(3 \mathrm{mg} \cdot \mathrm{mL}^{-1}\right)$ [23] and T. aurantiacus $\left(3.9 \mathrm{mg} \cdot \mathrm{mL}^{-1}\right)$ [26].

Purified enzyme illustrated highest activity with CMC as compare to rice husk, wheat straw and sucrose (Figure 6(c)), whereas cellulase enzyme produced from Trichoderma koningii reveal little ability to attack CMC as compare to cellotetraose and cellohexaose [27]. $\mathrm{NaCl}$, $\mathrm{MgSO}_{4}$, Tween 20 and EDTA are inhibitors of the enzyme and decrease the activity 5.32\%, 3.55\%, 5.32\% and $21.66 \%$ respectively with respect to control (Figure 6(d)).

\section{CONCLUSION}

Purification fold and recovery percentage of 13 and 23 respectively was achieved with solvent extraction pro- cess chosen as optimum for cellulase purification by RSM. The molecular weight of the enzyme was estimated to be $32.5 \mathrm{KDa}$. The $\mathrm{K}_{\mathrm{m}}$ of the purified enzyme for carboxy methyl cellulose, sodium salt (CMC), was $2.5 \mathrm{mg} \cdot \mathrm{mL}^{-1}$ at $\mathrm{pH}$ and temperature $6.5^{\circ} \mathrm{C}$ and $40^{\circ} \mathrm{C}$, respectively. Enzyme exhibited maximum substrate specificity for carboxymethyl cellulose with compare to rice husk, wheat straw and sucrose. The data obtained in this study will be used to shape the process for cellulase extraction for different aspects of higher purification yields.

\section{REFERENCES}

[1] Whitaker, J. (1990). Cellulase production and applications. Food Biotechnology, 4, 669-697. doi:10.1080/08905439009549782

[2] Solomon, B., Amigun, B., Betiku, E., Ojumu, T. and Layokun, S. (1997) Optimization of cellulase production by Aspergillus flavus linn isolate NSPRI101 grown on bagasse. Nigerian Society of Chemical Engineers, 16, 61-68.

[3] Beguin, P. and Aubert, J. (1994) The biological degration of cellulose. FEMS Microbiology Reviews, 13, 25-28. doi:10.1111/j.1574-6976.1994.tb00033.x 
[4] Kaur, J., Chadha, B., Kumar, A. and Saini, H. (2007) Purification and characterization of two endoglucanases from Melanocarpus sp. MTCC 3922. Bioresource Technology, 98, 74-81. doi:10.1016/j.biortech.2005.11.019

[5] Adsul, M., Bastawde, K., Varma, A. and Gokhale, D. (2007) Strain improvement of Penicillium janthinellum NCIM 1171 for increased cellulase production. Bioresource Technology, 98, 1467-1473. doi:10.1016/j.biortech.2006.02.036

[6] Silva, C. and Roberto, C. (2001) Optimization of xylitol production by Candida guilliermondii FTI 20037 using response surface methodology. Process Biochemistry, 36, 1119-1124. doi:10.1016/S0032-9592(01)00153-4

[7] Bhat, M. (2000) Cellulases and related enzymes in biotechnology. Biotechnology Advances, 18, 355-383. doi:10.1016/S0734-9750(00)00041-0

[8] Duff, S. and Murray, D. (1996) Bioconversion of forest products industry waste cellulosics to fuel ethanol: A review. Bioresource Technology, 55, 1-33. doi:10.1016/S0734-9750(00)00041-0

[9] Nieves, R., Ehrman, C., Adney, W., Elander, R. and Himmel, M. (1998) Technical communication: Survey and analysis of commercial cellulase preparations suitable for biomass conversion to ethanol. World Journal of Microbiology and Biotechnology, 14, 301-304. doi:10.1023/A:1008871205580

[10] Chahal, S., Chahal, D. and Andre, G. (1992) Cellulase production profile of Trichoderma reesei on different cellulosic substrates at various $\mathrm{pH}$ levels. Journal of Fermentation and Bioengineering, 74, 126-128. doi:10.1016/0922-338X(92)80015-B

[11] Reczey, K., Szengyel, R. and Zacchi, G. (1996) Cellulase production by T. reesei. Bioresource Technology, 57, 2530. doi:10.1016/0960-8524(96)00038-7

[12] Dey, R., Mitra, M. and Banerjee, B. (2001) Enhanced production of amylase by optimization of nutritional constituents using response surface methodology. Biochemical Engineering Journal, 7, 227-231. doi:10.1016/S1369-703X(00)00139-X

[13] Kristo, E., Biliaderis, C. and Tzanetakis, N. (2003) Modelling of the acidification process and rheological properties of milk fermented with a yogurt starter culture using response surface methodology. Food Chemistry, 83, 437446. doi:10.1016/S0308-8146(03)00126-2

[14] Chen, F., Cai, T., Zhao, G., Liao, X., Guo, L. and Hu, X. (2005) Optimizing conditions for the purification of crude octacosanol extract from rice bran wax by molecular distillation analyzed using response surface methodology. Journal of Food Engineering, 70, 47-53. doi:10.1016/i.jfoodeng.2004.09.011

[15] Miller, G. (1959) Use of dinitrosalicylic acid regent for determination of reducing sugar. Analytical Chemistry,

\section{1, 426-428. doi:10.1021/ac60147a030}

[16] Lowry, O., Rosebrough, N., Farr, V. and Randall, R. (1951) Protein measurement with the Folin phenol reagent. The Journal of Biological Chemistry, 193, 265-275.

[17] Laemmli, U. (1970) Cleavage of structural proteins during the assembly of the head of becteriophage T4. Nature (London), 227, 680-685. doi:10.1038/227680a0

[18] Lineweaver, H. and Burk, D. (1934). The determination of enzyme dissociation constants. Journal of the American Chemical Society, 56, 658-666. doi:10.1021/ja01318a036

[19] Eriksen, J. and Goksoyr, J. (1977) Cellulases from Chaetomium thermophile var. dissitum. European Journal of Biochemistry, 77, 445-450. doi:10.1111/j.1432-1033.1977.tb11685.x

[20] Ganju, R., Murthy, S. and Vithayathil, J. (1990) Purification and functional characteristics of a cellulase from Chaetomium thermophile var. coprophile. Carbohydrate Research, 197, 245-255. doi:10.1016/0008-6215(90)84147-M

[21] Hayashida, S. and Yoshioka, H. (1980) The role of carbohydrate moiety on thermostability of cellulases from Humicola insolens YH-8. Agricultural Biology and Chemistry, 44, 481-487. doi:10.1271/bbb1961.44.481

[22] Rao, U. and Murthy, S (1988) Purification and characterization of a glucosidase and cellulase from Humicola insolens. Indian Journal of Biochemistry \& Biophysics, 25, 687-694.

[23] Roy, K., Dey, S., Raha S. and Chakrabarty, S. (1990) Purification and properties of an extracellular endoglucanase from Myceliophthora thermophila D-14 (ATCC 48104). Journal of General Microbiology, 136, 1967-1971. doi:10.1099/00221287-136-10-1967

[24] Sharma S, Malik. A. and Satya, S. (2009) Application of response surface methodology (RSM) for optimization of nutrient supplementation for Cr (VI) removal by Aspergillus lentulus AML05. Journal of Hazardous Materials, 164, 1198-1204. doi:10.1016/j.jhazmat.2008.09.030

[25] Gavin, M. and Forsberg, C.W. (1988) Isolation and characterization of endoglucanases 1 and 2 from Bacteroides succinogenes S85. Journal of Bacteriology, 170, 2914-2922.

[26] Tong, C., Cole, A. and Shephert, M. (1980) Purification and properties of the cellulases from the thermophilic fungus Thermoascus aurantiacus. Biochemical Journal, 191, 83-94.

[27] Wood, T.M. and McCrae, S.I (1978) The cellulase of Trichoderma koningii. Purification and properties of some endoglucanase components with special reference to their action on cellulose when acting alone and in synergism with the cellobiohydrolase. Biochemical Journal, 171, $61-72$. 